\title{
Porsonomonoser
}

2019, vol. 81, 97-104

http://dx.doi.org/10.12657/denbio.081.011

\author{
Barbara Bujarska-Borkowska, Jan Suszka
}

\section{Seed dormancy breaking under controlled conditions in ornamental Cotoneaster spp.}

Received: 5 June 2019; Accepted: 23 August 2019

\begin{abstract}
Seeds of numerous trees and shrubs require specific environmental conditions to initiate germination. In the genus Cotoneaster, seeds often remain dormant in the ground for 1-2 years. Therefore, knowledge of the method of breaking seed dormancy under controlled conditions is needed. Various temperatures of stratification and chemical scarification were tested in this work to break deep double seed dormancy under controlled conditions in C. divaricatus, C. horizontalis and C. hupehensis. Fruits were collected in October, when they were fully ripe. The seeds extracted from the fruits were air-dried at room temperature to a moisture content of approximately $10 \%$. Fresh and air-dried seeds were subjected to different variants of cold stratification or warm-cold stratification with different alternating temperatures. The hard seeds of $C$. hupehensis were also scarified in concentrated sulfuric acid, followed by warm stratification. A seed was counted as germinated when a 1-3 mm long radicle appeared. After stratification (ca. 5\% seed germination), seeds were tested for germination and emergence. The dormancy of air-dried C. divaricatus and C. horizontalis seeds was broken most effectively by stratification for $12-16$ weeks at $20^{\circ} / 30^{\circ} \mathrm{C}(16 / 8$ hours), followed by $15-18$ weeks at $3^{\circ} \mathrm{C}$. Scarification in concentrated sulfuric acid for 3 hours followed by warmcold stratification at $20^{\circ} / 30^{\circ} \mathrm{C}\left(4\right.$ weeks) and $3^{\circ} \mathrm{C}$ (18 weeks) resulted in the highest germination (48\%) of C. hupehensis seeds at $3 \% / 20^{\circ} \mathrm{C}(16 / 8$ hours). In our experiment, we demonstrated that the physiological and physical dormancy of Cotoneaster species can be broken under controlled conditions with stratification or stratification combined with scarification methods.
\end{abstract}

Keywords: Cotoneaster divaricatus, C. horizontalis, C. hupehensis, dormancy, stratification, scarification, germination, seedling emergence.

Address: Institute of Dendrology, Polish Academy of Sciences, Kórnik, Poland, e-mail: bbujarska-borkowska@wp.pl; jsuszka@man.poznan.pl

\section{Introduction}

Cotoneasters (Cotoneaster spp., family Rosaceae) belong to a major group of ornamental shrubs. They have colorful fruits and leaves, which turn red, orange or yellow in autumn. The shrubs vary in height from very low prostrate plants to tall erect ones. They are native to Asia (Himalayas, China). The genus includes
50-400 species, depending on classification (because of the similarity and hybridization of many species). There are four wild species in Poland that are not used in urban green areas or in gardens (Mirek et al., 2002; Seneta \& Dolatowski, 2011). This study focused on three introduced ornamental species, namely, C. horizontalis, C. divaricatus and C. hupehensis. C. horizontalis Decne., also known as rockspray cotoneaster, is a 
low shrub $(50-60 \mathrm{~cm})$ with prostrate twigs. Native to western China but commonly cultivated in Europe, it is one of the most valued shrubs for rock gardens, low slopes, and flower beds. C. divaricatus Rehder \& E. H. Wilson, also known as spreading cotoneaster, is one of the most widely grown ornamental species, with beautiful leaf colors in autumn and abundant fruits. It is a shrub, growing $1.5-2 \mathrm{~m}$ tall, with prostrate twigs and fruits that persist until November. The species is suitable for group planting and hedgerows (Bugała, 2000). C. hupehensis Rehder \& E. H. Wilson (syn. C. silvestrii Pamp.), also known as Hupeh cotoneaster, is a shrub from China reaching up to $2 \mathrm{~m}$ in height with yellow inflorescences composed of many flowers, brown fruits (with two seeds each) and slightly tomentose leaves (Mirek et al., 2002).

Cotoneaster fruits contain one to five seeds (Rehder, 1951; Slabaugh, 1974; Slabaugh \& Shaw, 2008; Seneta \& Dolatowski, 2011). Seeds of the Rosaceae family are characterized by deep double dormancy, i.e., physical dormancy (caused by the hard endocarp and seed coat) and physiological dormancy of the embryo (Tyszkiewicz \& Dąbrowska, 1953; Nikolaeva, 1967; Lang et al., 1987; Hartmann et al., 1997; Baskin \& Baskin, 2004). Published data indicate that cotoneasters are propagated from seeds, which need a period of cold stratification from three months to two years (Bärtels, 1982; Terpiński, 1984; Hrynkiewicz-Sudnik et al., 1987). Germination may be accelerated by warm-cold stratification for 2-3 months or scarification (before cold stratification) in concentrated sulfuric acid (Kamiński, 1985; Meyer, 1988; Bugała, 2000). After such pretreatment, seeds sown in spring germinate quickly, but their germination capacity is often low. The objective of this study was to determine the optimum stratification conditions for these three ornamental Cotoneaster species. Three questions were investigated. First, do the temperature and duration of seed stratification affect dormancy breaking? Second, how does scarification influence germination? Third, does air-drying of seeds after collection influence their germination?

\section{Material and methods}

\section{Seed collection}

Ripe fruits of Cotoneaster divaricatus and C. horizontalis were collected in October 2005 and/or October 2006 from two sites in western Poland: the Kórnik Arboretum (52 $\left.24^{\prime} 23^{\prime \prime} \mathrm{N} ; 17^{\circ} 07^{\prime} 55^{\prime \prime} \mathrm{E}\right)$ and an urban park in Osiedle Oświecenia in Poznań $\left(52^{\circ} 23^{\prime} 22^{\prime \prime} \mathrm{N}\right.$; $16^{\circ} 57^{\prime} 39^{\prime \prime E}$ ) (Table 1). Seeds of C. hupehensis were also collected in October 2006 in Kórnik.

After removal of the pericarp, some seeds were airdried for 10 days at room temperature to a moisture content (mc) of approximately 10,0\%. Seed mc was determined on a dry weight basis after 24 hours at $105^{\circ} \mathrm{C}$. The filled seed percentage was assessed by a cut test.

\section{Stratification, scarification, germination, and seedling emergence}

All seeds were stratified in moist medium (quartz sand and acidic peat, $1: 1$ ). The seeds were mixed with the medium at a volume ratio of $1: 3$ and placed in 0.2 1 plastic bottles. Plastic lids with three holes (each 50 $\mathrm{mm}$ in diameter) were fitted to protect against excessive drying while allowing gas exchange. At the end of stratification, germination tests (three replicates of 50 seeds (sand and acidic peat, volume ratio of $1: 1 ; \mathrm{pH}$ of $3.5-4.5)$ were conducted at $3^{\circ} / 20^{\circ} \mathrm{C}(16 / 8$ hours) or at $3^{\circ} \mathrm{C}$. Germination was checked every week, and water was added as required. Seeds with radicles $>3 \mathrm{~mm}$ long were regarded as germinated.

Soon after collection, an experiment was established with fresh (24-28\% mc) and dried (8.8-11.5\%) seeds of $C$. horizontalis, $C$. divaricatus and $C$. hupehensis (seed lots 1, 4, 5, and 7) and with air-dried seeds only of $C$. horizontalis and C. divaricatus (seed lots 2, 3, and $6)$. Seeds were stratified for 12,16 or 20 weeks at three constant temperatures $\left(15^{\circ}, 20^{\circ}, 25^{\circ} \mathrm{C}\right)$ or three cyclically alternating temperatures $\left(15^{\circ} / 20^{\circ}, 15^{\circ} / 25^{\circ}\right.$ and $20^{\circ} / 30^{\circ} \mathrm{C}$ (16/8 hours)), followed by $15-18$ weeks at $3^{\circ} \mathrm{C}$, i.e., to the time when the first radicles started to appear (2-4\%). Afterwards, the seeds were kept at $3 \% / 20^{\circ} \mathrm{C}(16 / 8$ hours) and subjected to separate germination or seedling emergence tests in the same medium as that used for stratification, which lasted 10 weeks.

Because fresh and dried seeds of $C$. hupehensis (seed lot 7) did not germinate after warm-followedby-cold stratification later in the experiment, such seeds were scarified before stratification (Fig. 1). Dried seeds of $C$. hupehensis were scarified in concentrated sulfuric acid for 1, 2 or 3 hours, followed by soaking in water for 24 hours and cold stratification alone $\left(3^{\circ} \mathrm{C}\right.$ for 22 weeks) or warm-cold stratification $\left(20^{\circ} / 30^{\circ} \mathrm{C}\right.$ for four weeks, then $3^{\circ} \mathrm{C}$ for 18 weeks). Due to a limited number of seeds, only two stratification methods (one with a warm phase) were used for $C$. hupehensis. Finally, seed germination was tested at $3^{\circ} / 20^{\circ} \mathrm{C}$ (16/8 hours) (Fig. 1).

Seedling emergence tests were performed only for C. horizontalis and C. divaricatus seeds after stratification (Fig. 1). Germinating seeds were transferred to plastic growing trays (HIKO V-50; $352 \times 216 \times 87 \mathrm{~mm}$ with 67 cells each) and sown at a depth of $20 \mathrm{~mm}$. The trays were placed in a greenhouse (plastic tunnel) and filled with a mixture of acidic peat ( $\mathrm{pH}$ of $3.5-4.5$ ) and perlite at a ratio of 3:1. The trays were 
Cotoneaster horizontalis, C. divaricatus and C. hupehensis (seed lot 1-7)

\begin{tabular}{ccc}
\hline Stratification & Tests \\
\hline warm phase & cold phase & \\
$15^{\circ}, 20^{\circ}, 25^{\circ} \mathrm{C}$ & & \\
$15^{\circ} / 20^{\circ}, 15^{\circ} / 25^{\circ}, 20^{\circ} / 30^{\circ} \mathrm{C}$ & & $3^{\circ} / 20^{\circ} \mathrm{C} \mathrm{G}, \mathrm{S}$ \\
$(16 / 8$ hours $)$ & & \\
$(12,16$ or 20 weeks $)$ & $3^{\circ} \mathrm{C} \quad$ germ. \\
& $(15-18$ weeks $)$
\end{tabular}

Cotoneaster hupehensis (seed lot 7)

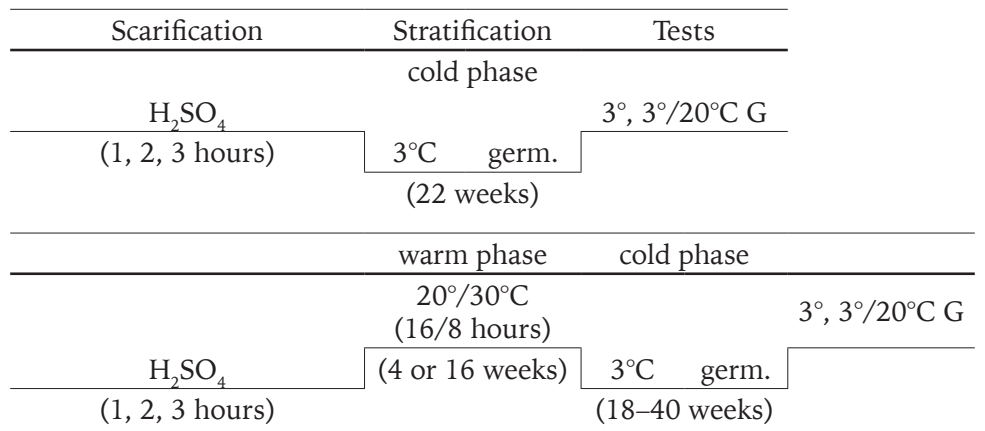

Fig. 1. Scheme of experiments on dormancy breaking of Cotoneaster horizontalis, C. divaricatus and C. hupehensis seeds germ. - initiation of germination ( $2-4 \%)$; G - germination test; $\mathrm{S}$ - seedling emergence test.

sprinkled with tap water every day. After germination and seedling emergence tests, cut tests of ungerminated seeds were repeated if germination and seedling emergence were low. Most of the seeds appeared to be healthy.

JMP software (version 7.0.2; SAS Institute, Cary, NC) was used for statistical analyses of the data. Analysis of variance (ANOVA), using a mixed model with "seed lot" as a random effect, was used to assess the influence of moisture content, stratification temperature and duration and scarification duration on the level of seed germination and seedling emergence. This method of analysis allowed us to investigate the general germinability of cotoneaster seeds without distinction among individual seed lots. All percentage data were arc sin transformed prior to statistical analyses. Tukey's test was used to determine significant differences between sample means at $\mathrm{P}=0.05$.

\section{Results}

\section{Seed germination and seedling emergence in $C$. horizontalis and $C$. divaricatus}

Fresh seeds of both species, in all the applied stratification systems, had a lower germination capacity than air-dried seeds. For fresh seeds of $C$. horizontalis, the average germination value was $21 \%$, while for fresh seeds of $C$. divaricatus, it was $45 \%$ (Fig. 2, Table 2).

In our analyses, seed lot was treated as a random factor; however, the reactions of $C$. horizontalis seeds from different places of harvest to the stratification treatments were different. In this case, analysis of variance components showed that seed lot explained up to $74 \%$ of the variability.

Table 1. Characteristics of seed lots

\begin{tabular}{lcccccc}
\hline Cotoneaster species & Seed lot & Collection site & Collection date & $\begin{array}{c}\text { Moisture content of } \\
\text { fresh seeds (\%) }\end{array}$ & $\begin{array}{c}\text { Moisture content of } \\
\text { dried seeds (\%) }\end{array}$ & $\begin{array}{c}\text { Filled seeds in cut-test } \\
(\%)\end{array}$ \\
\hline C. horizontalis & 1 & Kórnik & 06 Oct. 2005 & 24.2 & 9.5 & 90.0 \\
& 2 & Poznań & 27 Oct. 2005 & n.d. & 9.5 & 83.6 \\
& 3 & Poznań & 26 Oct. 2006 & n.d. & 9.3 & 91.3 \\
C. divaricatus & 4 & Kórnik & 06 Oct. 2005 & 25.5 & 9.7 & 87.5 \\
& 5 & Poznań & 27 Oct. 2005 & 28.0 & 8.8 & 90.2 \\
& 6 & Kórnik & 26 Oct. 2006 & n.d. & 9.2 & 98.0 \\
C. hupehensis & 7 & Kórnik & 19 Oct. 2006 & 24.4 & 11.5 & 88.3 \\
\hline
\end{tabular}

n.d. $=$ no data. 
For air-dried seeds of $C$. horizontalis, the best treatment was warm-cold stratification at $20^{\circ} \mathrm{C}$ or $15 / 20^{\circ} \mathrm{C}$ followed by $3^{\circ} \mathrm{C}$ for 16 weeks, when germination reached an average of 61 and 59\%, respectively. Seeds
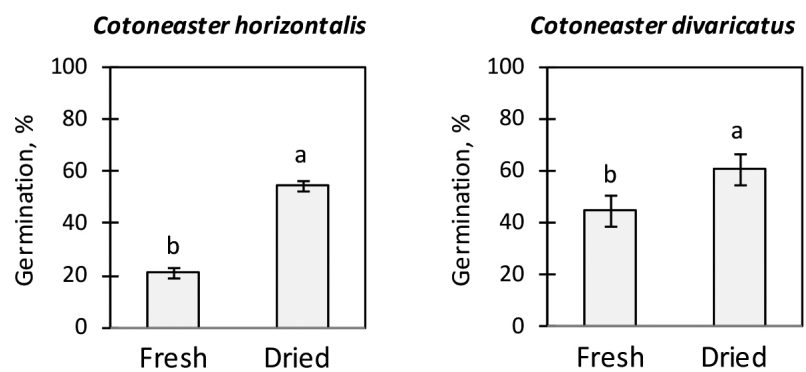

Fig. 3. Effect of temperature of the stratification warm phase on mean $( \pm \mathrm{SE})$ seed germination at $3^{\circ} / 20^{\circ} \mathrm{C}$ (16/8 h): (A) Cotoneaster horizontalis, seed lots 1 and 2 ; (B) C. divaricatus, seed lots 4 and 5 . Air-dried seeds (mc of $9 \%$ ). Bars marked with different letters differ significantly (Tukey's test, $P \leq 0.05$ )

\section{(A) Cotoneaster horizontalis}

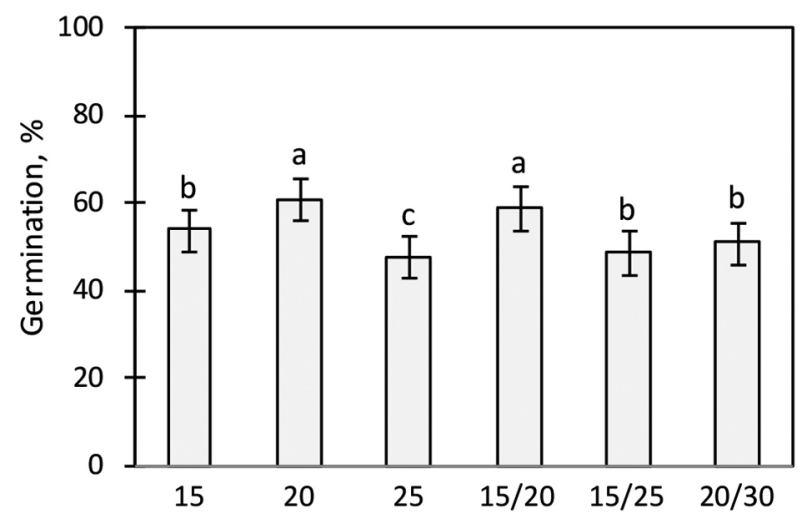

Temperature of stratification warm phase, ${ }^{\circ} \mathrm{C}$ stratified in the warm phase in other conditions germinated significantly less, but the differences were not large (Fig. 3A). The duration of the warm stratification phase (between 12 and 20 weeks) had no significant effect on seed germination (Fig. 4A).

Table 2. Statistical analysis of the effect of drying seeds (moisture content: $25 \%$ and $9 \%$ ) and stratification conditions in the warm phase $\left(15^{\circ} \mathrm{C}, 20^{\circ} \mathrm{C}, 25^{\circ} \mathrm{C}, 15 / 20^{\circ} \mathrm{C}\right.$, $15 / 25^{\circ} \mathrm{C}$ and $20 / 30^{\circ} \mathrm{C}$ ) on Cotoneaster horizontalis and Cotoneaster divaricatus seed germination. ANOVA mixed model with "seed lot" as a random effect

\begin{tabular}{|c|c|c|c|c|c|c|}
\hline & \multicolumn{3}{|c|}{ C. horizontalis } & \multicolumn{3}{|c|}{ C. divaricatus } \\
\hline Source variance & DF & $\mathrm{F}$ & $P$ & DF & $\mathrm{F}$ & $P$ \\
\hline $\begin{array}{l}\text { Moisture content } \\
\text { (MC) }\end{array}$ & 1 & 135.4 & 0.0001 & 1 & 36.8 & 0.0001 \\
\hline $\begin{array}{l}\text { Stratification condi- } \\
\text { tions (SC) }\end{array}$ & 5 & 7.2 & 0.0003 & 5 & 17.9 & 0.0001 \\
\hline$M C * S C$ & 5 & 7.2 & 0.0001 & 5 & 2.9 & 0.0217 \\
\hline
\end{tabular}

$\mathrm{DF}$ - degrees of freedom, $\mathrm{F}$ - ratio, $\mathrm{P}$ - probability.

(B) Cotoneaster divaricatus

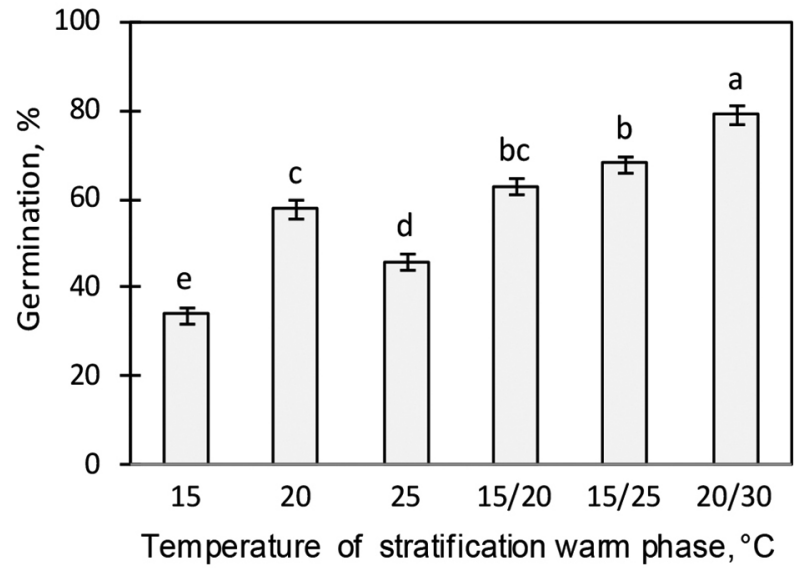

Fig. 3. Effect of temperature of the stratification warm phase on mean $( \pm \mathrm{SE})$ seed germination at $3^{\circ} / 20^{\circ} \mathrm{C}(16 / 8 \mathrm{~h})$ : (A) Cotoneaster horizontalis, seed lots 1 and 2; (B) C. divaricatus, seed lots 4 and 5. Air-dried seeds (mc of 9\%). Bars marked with different letters differ significantly (Tukey's test, $P \leq 0.05$ )

(A) Cotoneaster horizontalis

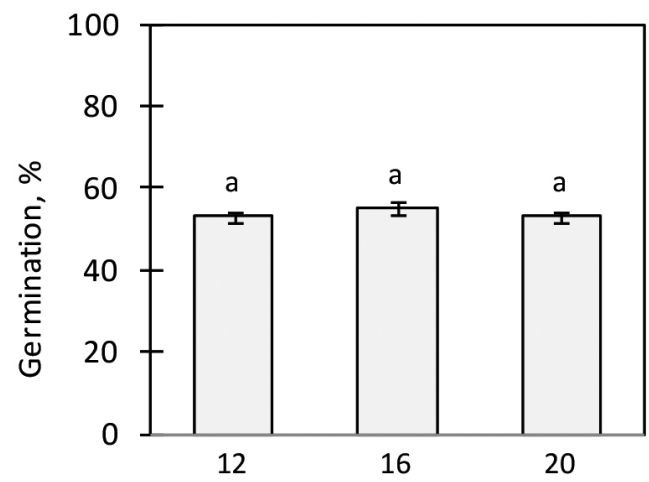

Duration of stratification warm phase, weeks
(B) Cotoneaster divaricatus

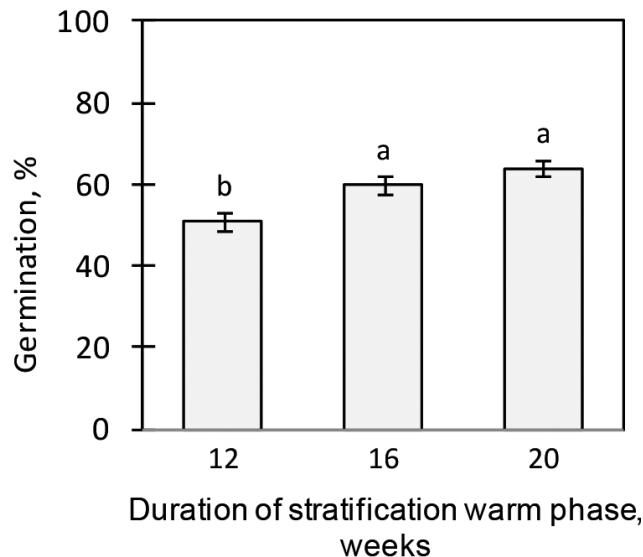

Fig. 4. Effect of duration of the stratification warm phase on mean $( \pm \mathrm{SE})$ seed germination at $3^{\circ} / 20^{\circ} \mathrm{C}(16 / 8 \mathrm{~h})$ : $(\mathrm{A})$ Cotoneaster horizontalis, seed lots 1 and 2; (B) C. divaricatus, seed lots 4 and 5. Air-dried seeds (mc of 9\%). Bars marked with different letters differ significantly (Tukey's test, $P \leq 0.05$ ) 
For air-dried seeds of $C$. divaricatus, the highest germination $(79 \%)$ was observed after warm-cold stratification with a warm phase at cyclically variable temperatures of $20^{\circ} / 30^{\circ} \mathrm{C}$ followed by $3^{\circ} \mathrm{C}$ (Fig. 3B).

In the case of $C$. divaricatus, seeds displayed the highest percentage of germination when the stratification warm phase lasted 16 or 20 weeks $(60 \%$ or $64 \%$, respectively), which was significantly more germination than that observed after 12 weeks (Fig. 4B).

There was a significant interaction between the conditions (temperature) and duration of seed stratification for C. divaricatus (Table 3). Generally, the number of germinating seeds increased with increasing temperature and duration of the warm stratification phase; however, the extension of this phase to 20 weeks at $15{ }^{\circ} \mathrm{C}$ and especially at $25^{\circ} \mathrm{C}$ resulted in a radical decrease in germination (Fig. 5).

The highest average seedling emergence $(63 \%$ in C. horizontalis and $55 \%$ in C. divaricatus) was recorded

(A) Cotoneaster horizontalis

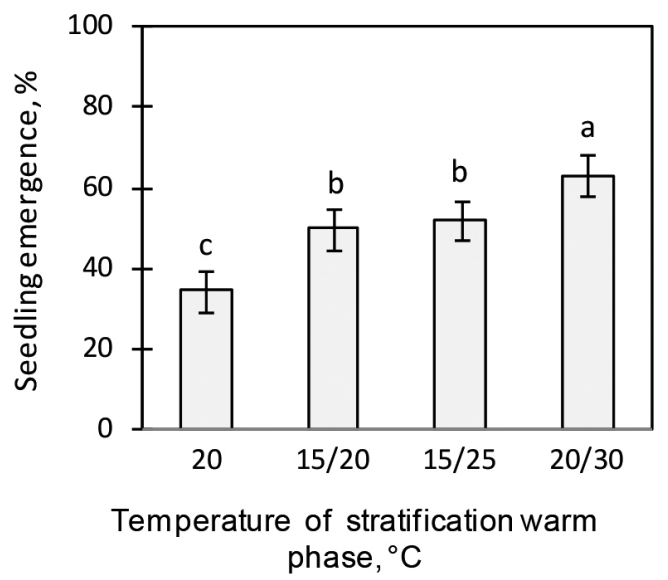

after warm-cold stratification at $20^{\circ} / 30^{\circ} \mathrm{C}$ (Fig. 6). The duration of warm phase stratification had a significant effect on seedling emergence. Extending the

Cotoneaster divaricatus

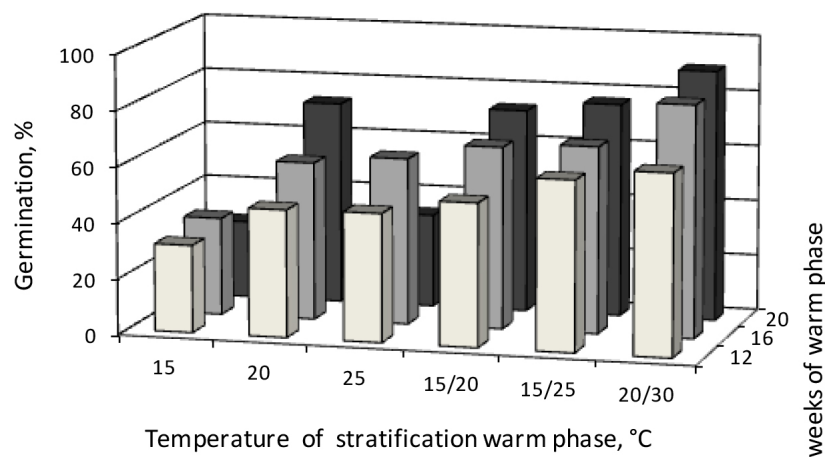

Fig. 5. Effect (interaction) of temperature and duration of the warm phase of stratification on seed germination at $3^{\circ} / 20^{\circ} \mathrm{C}$ (16/8 h): C. divaricatus, seed lots 4 and 5. Airdried seeds (mc of $9 \%$ )

(B) Cotoneaster divaricatus

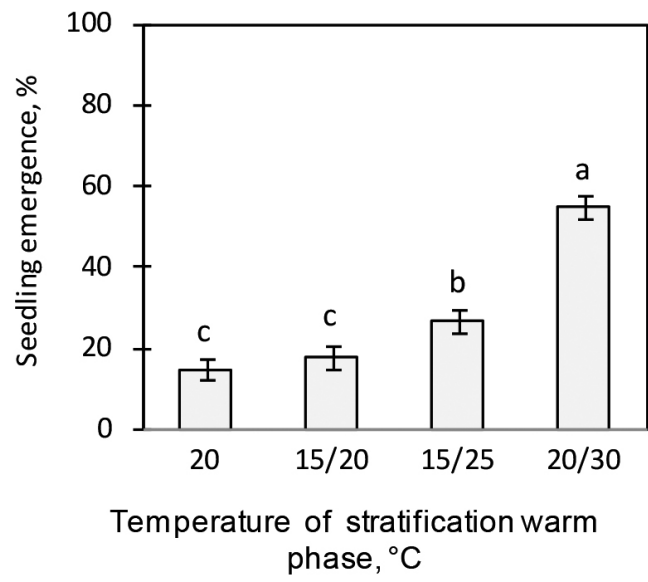

Fig. 6. The effect of various regimes of warm-cold stratification on mean $( \pm \mathrm{SE})$ seedling emergence at $3^{\circ} / 20^{\circ} \mathrm{C}(16 / 8 \mathrm{~h})$ with the warm phase lasting 12 or 16 weeks: (A) Cotoneaster horizontalis, seed lot 3; (B) C. divaricatus, seed lot 6 . Bars marked with different letters differ significantly (Tukey's test, $P \leq 0.05$ )

Table 3. Statistical analysis of the effect of stratification conditions in the warm phase $\left(15^{\circ} \mathrm{C}, 20^{\circ} \mathrm{C}, 25^{\circ} \mathrm{C}, 15 / 20^{\circ} \mathrm{C}\right.$, $15 / 25^{\circ} \mathrm{C}$ and $\left.20 / 30^{\circ} \mathrm{C}\right)$ and duration of the warm phase $(12,16$ and 20 weeks) on Cotoneaster horizontalis and Cotoneaster divaricatus seed germination. ANOVA mixed model with "seed lot" as a random effect

\begin{tabular}{|c|c|c|c|c|c|c|}
\hline \multirow[b]{2}{*}{ Source variance } & \multicolumn{3}{|c|}{ C. horizontalis } & \multicolumn{3}{|c|}{ C. divaricatus } \\
\hline & DF & $\mathrm{F}$ & $P$ & $\mathrm{DF}$ & $\mathrm{F}$ & $P$ \\
\hline Stratification conditions (SC) & 5 & 4.6 & 0.0009 & 5 & 140.1 & 0.0001 \\
\hline Stratification time (ST) & 2 & 0.6 & 0.5417 & 2 & 59.7 & 0.0001 \\
\hline $\mathrm{MC} * \mathrm{ST}$ & 10 & 0.7 & 0.6855 & 10 & 14.7 & 0.0001 \\
\hline
\end{tabular}

$\mathrm{DF}$ - degrees of freedom, $\mathrm{F}$ - ratio, $\mathrm{P}$ - probability.

Table 4. Statistical analysis of the effect of stratification conditions in the warm phase $\left(20^{\circ} \mathrm{C}, 15 / 20^{\circ} \mathrm{C}, 15 / 25^{\circ} \mathrm{C}\right.$ and $20 / 30^{\circ} \mathrm{C}$ ) and duration of the warm phase (12 and 16) on Cotoneaster horizontalis and Cotoneaster divaricatus seedling emergence. ANOVA mixed model with "seed lot" as a random effect

\begin{tabular}{lcccccc}
\hline & \multicolumn{3}{c}{ C. horizontalis } & \multicolumn{3}{c}{ C. divaricatus } \\
\hline Source variance & DF & F & $P$ & DF & F & $P$ \\
Stratification conditions (SC) & 3 & 131.7 & 0.0001 & 3 & 88.1 & 0.0001 \\
Stratification time (ST) & 1 & 46.5 & 0.0001 & 1 & 93.6 & 0.0001 \\
SC*ST & 3 & 1.5 & 0.261 & 3 & 6.7 & 0.004 \\
\hline
\end{tabular}

$\mathrm{DF}$ - degrees of freedom, $\mathrm{F}$ - ratio, $\mathrm{P}$ - probability. 
stratification time from 12 to 16 weeks resulted in a significant increase in emergence, especially in the case of $C$. divaricatus after stratification at $20 / 30^{\circ} \mathrm{C}$ (73\%) (significant interaction, Table 4).

\section{Seed germination in C. hupehensis}

In preliminary experiments with fresh and airdried seeds of $C$. hupehensis, the seeds did not germinate in any of the tested thermal regimes (data not shown), despite the high percentage $(88 \%)$ of filled seeds in the cutting test. Air-dried seeds of C. hupehensis germinated when their stratification was preceded by scarification. Germination capacity at $3^{\circ} / 20^{\circ} \mathrm{C}$ was the highest (48\%) after chemical scarification for 3 hours and warm-cold stratification at $20^{\circ} / 30^{\circ} \mathrm{C}$ for 4 weeks followed by $3^{\circ} \mathrm{C}$ for 22 weeks. Seeds stratified only at $3^{\circ} \mathrm{C}$ germinated significantly less. Additionally, a shorter period of scarification (1-2 hours) was less effective (Fig. 7).
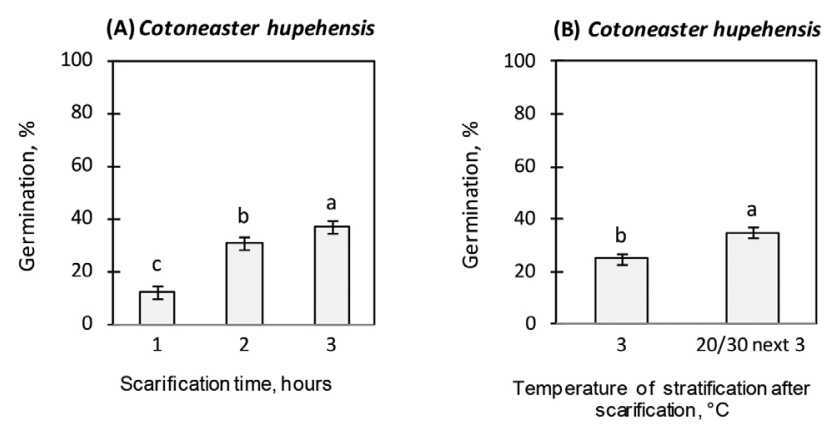

Fig. 7. Cotoneaster hupehensis. The effect of different scarification durations in sulfuric acid and stratification conditions on the final mean $( \pm \mathrm{SE})$ seed germination capacity. (A) Seeds stratified at $3^{\circ} \mathrm{C}$ for 22 weeks after 1,2 or 3 hours of scarification. (B) Seeds stratified after scarification either at $3^{\circ} \mathrm{C}$ only or subjected to warm phase $20^{\circ} / 30^{\circ} \mathrm{C}(16 / 8$ hours) for 4 weeks followed by a cold phase at $3^{\circ} \mathrm{C}$ for 18 weeks. Bars marked with different letters differ significantly (ANOVA, Tukey's test, $P \leq 0.05)$

\section{Discussion}

The first successful experiments on breaking deep seed dormancy using scarification in sulfuric acid and different types of stratification of both fresh and airdried seeds of Cotoneaster spp. were described in this work. Various warm-cold stratification systems and methods of chemical scarification of seeds have previously been recommended (Macdonald, 1993; Nikolaeva et al., 1985; Dirr \& Heuser, 1987, 2006; Bird, 1990; Tylkowski, 2016). In this study, new thermal regimes of warm-cold stratification were tested, with varying durations of the warm stage of stratification. Our results show that chemical scarification, recommended by the cited authors, is unnecessary in $C$. divaricatus and C. horizontalis since high seed germination and seedling emergence can be obtained by warm-cold stratification in a peat-sand mixture under thermal conditions suitable for germination and growth.

Air-drying of cotoneaster seeds resulted in higher levels of germination. The results of some previous studies confirm our observations. Freshly collected, mature seeds are characterized by deep embryo dormancy, which is gradually broken during drying. The moisture content limit of the seed depends on the species. Cotoneaster seeds are classified as orthodox, so they can be dried to low levels of moisture. This method is commonly used to break seed dormancy. Under the influence of warmth, the physiological immaturity of the embryo is removed. Additionally, abscisic acid activity declines, and cytokinin activity slightly increases (Finch-Savage \& Leubner-Metzger, 2006).

Physical seed dormancy (also observed in cotoneasters) is caused by the waterproof layer of palisade cells in the seed coat, which controls water circulation. This type of dormancy can be effectively broken by mechanical or chemical scarification and by stratification. During stratification, hard seed coats are slowly decomposed by soil microorganisms, giving the embryo access to oxygen-rich air as well as water, which is necessary for the restoration of life processes (Baskin, 2003). In this study, the seed coat was thinnest in C. horizontalis, intermediate in C. divaricatus, and thickest in $C$. hupehensis. This difference is why seeds of $C$. horizontalis require a shorter warm stratification (12-16 weeks) than seeds of $C$. divaricatus (16-20 weeks) for germination, while the dormancy of seeds of $C$. hupehensis is broken only after scarification in sulfuric acid.

Environmental conditions affect seed dormancy breaking and germination capacity. The most promising way to understand this phenomenon is to study not only the morphological characters but also the physiological diversity of seeds in combination with plant taxonomy, ecology and geographical factors (Nikolaeva, 2004). Important factors also include earlier conditions of seed maturation (photoperiod, temperature, and light intensity). In combination with environmental factors, these factors may be crucial for understanding seed dormancy mechanisms. We observed this phenomenon in the case of $C$. horizontalis, where seed lot (seeds were collected at various locations) contributed significant variability.

Laboratory experiments eliminate environmental variation and should be linked with field research, which can provide specific insight into environmental protection for seeds of the selected species (Donohue, 2005). In our study, germination and seedling emergence tests were conducted in both the laboratory and the greenhouse; thus, environmental effects were also included. 
For seed dormancy breaking in the Rosaceae family, including the genus Cotoneaster, some authors have suggested the application of warm-cold stratification at constant temperatures. According to Bärtels (1982), Terpiński (1984) and Hrynkiewicz-Sudnik et al. (1987), a constant temperature of $20^{\circ} \mathrm{C}$ can be used. In our study, in the case of $C$. horizontalis, warmcold stratification with the warm stage at $20^{\circ} \mathrm{C}$ or cyclical temperatures of $15^{\circ} / 20^{\circ}, 15^{\circ} / 25^{\circ}$ and $20^{\circ} / 30^{\circ} \mathrm{C}$ (16/8 hours) broke seed dormancy, with similar effects. In the case of $C$. divaricatus seeds, stratification at cyclically alternating temperatures, especially at $20 / 30^{\circ} \mathrm{C}$, was a significantly better method.

Warm-cold seed stratification in C. hupehensis was unsuccessful, although $88 \%$ of seeds were filled in the cutting test. Kamiński (1985) and Meyer (1988) recommended cotoneaster seed scarification in concentrated sulfuric acid. Kamiński (1985) reported that after 30 or $45 \mathrm{~min}$ of $C$. divaricatus seed scarification with $96 \%$ sulfuric acid and cold stratification at $2-5^{\circ} \mathrm{C}, 80 \%$ of seeds germinated within 180 days.

The most effective pretreatment for $C$. hupehensis seeds in our research was scarification in concentrated sulfuric acid for 3 hours followed by warmcold stratification at $20^{\circ} / 30^{\circ} \mathrm{C}$ (4 weeks) and $3^{\circ} \mathrm{C}$ (22 weeks, i.e., until the first seedlings appeared); $48 \%$ germination was then observed at $3^{\circ} / 20^{\circ} \mathrm{C}$ (16/8 hours). A shorter scarification period and cold stratification alone also broke seed dormancy, but germination was lower than after stratification under the optimal thermal regime. This system has previously been recommended for other species of the family Rosaceae (Bujarska-Borkowska, 2008). We can assume that extending the duration of scarification of seeds to more than three hours would improve germination. However, we do not know the maximum time that does not cause damage to the seeds.

No seed germination was observed in our study after stratification at $3^{\circ} \mathrm{C}$ in $\mathrm{C}$. divaricatus, while in C. horizontalis, both germination and seedling emergence reached $35 \%$. A similar effect has been observed in other species: $2.5 \%$ emergence in C. nummularia after cold stratification (Olmez et al., 2006, 2007; Tilki, 2013). In the next stage of our research, we plan to use seed scarification and gibberellin treatment.

\section{Conclusions}

Seeds of Cotoneaster horizontalis are most effectively pretreated for germination by drying to approximately $10 \%$. The best method was warm-cold stratification in peat-sand medium at $20^{\circ}$ or $15 / 20^{\circ} \mathrm{C}$ $\left(20 / 30^{\circ} \mathrm{C}\right.$ in the case of emergence) for 12 to 20 weeks followed by $3^{\circ} \mathrm{C}$ for 16 weeks and, in the case of $\mathrm{C}$. divaricatus, at $20^{\circ} / 30^{\circ} \mathrm{C}$ for 16 to 20 weeks, also followed by $3^{\circ} \mathrm{C}$ for 16 weeks. Mean seed germination and seedling emergence were $74 \%$ (C. horizontalis) and $61 \%$ (C. divaricatus). During the warm phase of stratification, a cycling thermal regime should be applied (16/8 hours). Warm-cold stratification with the warm phase at $20^{\circ} \mathrm{C}, 25^{\circ} \mathrm{C}$ or $15^{\circ} / 25^{\circ} \mathrm{C}(16 / 8$ hours $)$ also breaks seed dormancy, but germination and seedling emergence values are then lower than those after stratification under the optimal thermal regime. After warm-cold stratification, germination and seedling emergence are nearly equally high at $3^{\circ} \mathrm{C}$ and at $3^{\circ} / 20^{\circ} \mathrm{C}(16 / 8$ hours). Seeds of $C$. hupehensis are most effectively pretreated by scarification in concentrated sulfuric acid for 3 hours and under warm-cold stratification at $20^{\circ} / 30^{\circ} \mathrm{C}$ for 4 weeks followed by $3^{\circ} \mathrm{C}$ for 22 weeks. After such pretreatment, $48 \%$ of seeds germinate at $3^{\circ} / 20^{\circ} \mathrm{C}(16 / 8$ hours $)$.

\section{Acknowledgements}

We are grateful to Dr. M. J. Giertych for his help with statistical analysis of the data and Prof. P. Chmielarz for reading the manuscript.

\section{Funding}

This work was supported by Polish Academy of Sciences, Institute of Dendrology.

\section{References}

Baskin CC (2003) Breaking physical dormancy in seeds - focussing on the lens. New Phytologist 158: 229-232.

Baskin JM \& Baskin CC (2004) A classification system for seed dormancy. Seed Science Research 14: $1-16$.

Bärtels A (1982) Rozmnażanie drzew i krzewów ozdobnych. Państwowe Wydawnictwo Rolnicze i Leśne Warszawa.

Bird R (1990) Growing from seed. Vol. 4. Thompson \& Morgan, Ipswich.

Bugała W (2000) Drzewa i krzewy. Państwowe Wydawnictwo Rolnicze i Leśne, Warszawa.

Bujarska-Borkowska B (2008) Seed dormancy breaking in Crataegus pedicellata. Dendrobiology 60: 51-56.

Dirr MA \& Heuser CW Jr (1987) The reference manual of woody plant propagation: from seed to tissue culture. Varsity Press, Athens, GA.

Dirr MA \& Heuser CW Jr (2006) The reference manual of woody plant propagation. Press. Inc., Cary, North Carolina.

Donohue K (2005) Seeds and seasons: interpreting germination timing in the field. Seed Science Research 15: 175-187. 
Finch-Savage WE \& Leubner-Metzger G (2006) Seed dormancy and the control of germination. New Phytologist 171: 501-523.

Hartmann HT, Kester DE, Davies FT Jr \& Geneve RL (1997) Plant propagation: principles and practices. 6 ed. Prentice Hall Inc., Upper Saddle River, New York.

Hrynkiewicz-Sudnik J, Sękowski B \& Wilczkiewicz M (1987) Rozmnażanie drzew i krzewów liściastych. Państwowe Wydawnictwo Naukowe, Warszawa.

Kamiński W (1985) Contribution towards better knowledge of pyracanth (Cotoneaster divaricata L.) seed dormancy. Acta Horticulturae 167: 441-447.

Lang GA, Early JD, Martin GC \& Darnell FL (1987) Endo-, para-, and ecodormancy: Physiological terminology and classification for dormancy research. Horticultural Science 22: 371-377.

Macdonald B (1993) Practical woody plant propagation for nursery growers. Vol. 1. Publisher Timber Press, Portland, Oregon.

Meyer MM Jr (1988) Rest and post dormancy of seeds of Cotoneaster species. Horticultural Science 23: 1046-1052.

Mirek Z, Piękoś-Mirkowa H, Zając A \& Zając M (2002) Flowering plants and pteridophytes of Poland. W. Szafer Institute of Botany Polish Academy of Sciences, Krakow.

Nikolaeva MG (1967) Physiology of deep dormancy of seeds. Academy of Sciences of USSR. Komarov Botanical Institute.

Nikolaeva MG (2004) On criteria to use in studies of seed evolution. Seed Science Research 14: 315320.

Nikolaeva MG, Rasumova MV \& Gladkova VN (1985) Reference book on dormant seed germination. Leningrad Nauka Publishers, Leningrad Branch.
Olmez Z, Temel F, Gokturk A \& Yahyaoglu Z (2006) Effect of cold stratification treatments on germination of drought tolerant shrubs seeds. Journal of Environmental Biology 28 (2 suppl.): 447-453.

Olmez Z, Gokturk A \& Temel F (2007) Effects of some pretreatments on seed germination of nine different drought-tolerant shrubs. Seed Science and Technology 35: 75-87.

Rehder A (1951) Manual of cultivated trees and shrubs. The Macmillan Company, New York.

Seneta W \& Dolatowski J (2011) Dendrologia. Państwowe Wydawnictwo Naukowe, Warszawa, pp. 227-274.

Slabaugh PE (1974) Cotoneaster B. Ehrh. Cotoneaster. Seeds of woody plants in the United States (ed. by CS Shopmeyer CS) Agriculture Handbook 450: 349-352.

Slabaugh PE \& Shaw NL (2008) Cotoneaster Medik.: cotoneaster: The woody plant seed manual (ed. by FT Bonner \& RP Karrfalt) Agriculture Handbook 727: 442-446.

Terpiński Z (1984) Szkółkarstwo ozdobne. Państwowe Wydawnictwo Rolnicze i Leśne, Warszawa.

Tilki F (2013) Seed germination of Cotoneaster nummularia as influenced by scarification, stratification, temperature and light. International Science and Technology Conference June 25-27. Rome, Italy, pp. 207-213.

Tylkowski T (2016) Przedsiewne traktowanie nasion drzew, krzewów, pnączy i krzewinek. Centrum Informacyjne Lasów Państwowych, Warszawa, pp. 146-148.

Tyszkiewicz S \& Dąbrowska J (1953) Stratification of seeds of forest trees and shrubs. Roczniki Nauk Leśnych 102: 155-224. 